Global Conferences Series:

Social Sciences, Education and Humanities (GCSSSEH), Volume 3, 2019

The $1^{\text {st }}$ International Conference on Education, Social Sciences and Humanities

DOI: https://doi.org/10.326/hum0190

\title{
New Media Literacy in the Context of Early Childhood Education (An Overview from Indonesian Kindergarten Future Teachers)
}

\section{Endah Silawati}

Universitas Pendidikan Indonesia, Bandung, Indonesia

$\left.{ }^{*}\right) \bowtie$ endah_silawati@upi.edu

\begin{abstract}
New era of global society 5.0 proposes some future skills that should be comprehended by students. One of the future skills is new media literacy which is a combination skills of media literacy, cultural literacy and information or technological literacy. Some recent studies have been conducted to investigate the best way of teaching NML skill from basic to higher education. However, there is still vagueness among researchers, parents and early childhood education teachers about how digital tools can collaborate effectively with traditional non-digital tools in children's daily lives. Therefore, this study investigates the understanding and perspectives of kindergarten future teachers in teaching new media literacy to children. Moreover, the qualitative approach is employed in this study through questioners and interviews. From data analysis, it can be concluded that future teachers comprehend very well in some aspects, such as, get familiar with various kinds of media that suitable for children. Nevertheless, they are still less comprehend in understanding other elements of new media literacy as well as its teaching strategies. Consequently, it is recommended to set this topic in some subjects on the curriculum of Early Childhood Teacher Education Study Program.
\end{abstract}

Keywords: New media literacy, ICT in the early years, Early childhood education,

\section{Introduction}

The society nowdasy is entering the era of 5.0 which is called as global and digital society (i-scoop, 2018). The sustainable innovation in this era is needed, including in educational aspects. To be successful in digital era, students have to acquire some skills which is called as future skills, such as resilience, cross-cultural competency, social intelligence, virtual collaboration, novel and adaptive thinking, cognitive load management, sense-making, design mindset, transdisciplinary, computational thinking and new media literacy (Fidler, 2016). One of the future skills that is urgent to be encourage in Indonesian society is New media literacy (refered to NML hereafter), because Indonesia is the third biggest country with most social media usage (kurnia, 2018). Without this skill, it is dreaded that social media will give negative effect to society and couse social conflict. In other hand, if the society have NML skill, it is assumed that social media will give positive effect and can be 
used as effective tool in sharing information, building collaboration and other beneficial effect to society.

NML is a combination skills of media literacy, cultural literacy and information or technology literacy (Luke, 2007). Some recent studies have been conducted to investigate the best way to teach NML skill from basic to higher education (Kara et al, 2018). However, the development of this skill in the context of early childhood education is still in question since there is still vagueness among researchers, parents and early childhood education teachers about how digital tools can collaborate effectively with traditional non-digital tools in children's daily lives (Alper, 2011). Therefore, investigation of NML skill in the context of early childhood education is important to be conducted.

Furthermore, many factors that invole in developing effectiveness of teaching NML to children. One of the crucial factor is teachers' understanding NML and their ability to teach NML to children. Additionally, teaching digital technology to children will be effective if teachers get suitable training, complete understanding and support links that combined with appropriate equipment, tools and resources (The Scottish Government, 2015). Actualy, this points has been stated in the lists of Indonesian kindergarten teachers' standard competences (Republic of Indonesia Law No. 14 Year 2005 on Teachers and Lecturers). Nevertheless, the broader skill than digital literacy, which is NML has not been stated on the standard competences. Moreover, according to the survey of graduates quality conducted by Study Program of Early Childhood Teacher Education of Cibiru Campus, Universitas Pendidikan Indonesia stated that the teacher's competence on Information and Technology skills as well as how to use ICT on teaching activities with children is still low (UPI Kampus Cibiru, 2018). Consequently, it is needed to improve the skill of the future teachers on NML a the efford of preparing them to be a good teacher in the future.

As the result, this study explores the understanding and perspectives of kindergarten future teachers in teaching NML to children. This study focus on describing future teachers on the definition of NML in the context of early childhood education as well as its elements and its teaching strategies. Result of this study will be beneficial for developing curriculum and learning materials to improve kindergarten future teachers on teaching NML to children.

\section{Method}

The participant of this study was 30 students of Early Childhood Teacher Education Study Program of Universitas Pendidikan Indonesia, Cibiru Campus. They study at sixth semester and as the future teacher of kindergarten, they should have comprehend understanding of NML and how to teach this skill to children. The sixth semester students were selected because they have studed some subjects that have relation with NML, such as: Media and ICT for children and Social Science for Children. Additionally, they were selected among 70 students randomly.

Furthermore, the qualitative approach (Creswell, 2012) was employed in this study and the data were collected through questioners and interviews. The questions were arrageded in three main sub topic such as: 1) Kindergarten future teachers' understanding on NML definition and elements, 2) Kindergarten future teachers' understanding on new media that suitable for children, and 3) Kindergarten future teachers' understanding on teaching NML to children. Those three sub topics were devided into 15 questions of open ended questions. Their answes were assessed though some criteria namely, fully comprehended if the future teachers have score 90 to 100, comprehended if the future teachers have score 80 to 90 , and less comprehended if the future teachers have score bellow 80. Moreover, interview were conducted to all 30 future teachers as triangulation and in depth interview were managed for some students who got the highes and the lowest score.

\section{Results and Discussion}

Kindergarten Future Teachers' Understanding on NML Definition and Elements 
The first part of the questioneres is to observe the future teachers' understanding on NML definition and elements. From the data anaysis, it can be concluded that most of the future teachers understand the definition of NML very well while only 3 future teachers who less comprehend the definition. In addition, 10 future teachers understand the definition but not in advance.

The next question is about the element of NML in the context of early childhood education. This part is arranged based on NML element from Jenkins (2006) such as; play, performance, simulation, appropriation, multitasking, distributed cognition, collective intelligence, judgment, transmedia navigation, networking and negotiation. From the data analysis, most of the future teachers not understand about the element of NML. Only 9 future teachers who get middle score and 2 future teacher who get the highest score. The number of frequency of each criteria is provided on the table bellow.

Table 1. Number of Frequency of Future Teachers' Understanding on NML Definition and Elements

\begin{tabular}{lccc}
\hline \multicolumn{1}{c}{ Future Teachers' Understanding } & \multicolumn{3}{c}{ Number of Frequency } \\
\cline { 2 - 4 } & Fully & Comprehended & Less \\
Definition of NML & Comprehended & 10 & Comprehended \\
NML Elements & 17 & 9 & 3 \\
\hline
\end{tabular}

Furthermore, the investigation is done in deeper strategy through the intervew of pasrticipats who get the highes and the lowest score. According to the interview, she has very well knowledge of NML definition and elements because she often whatches some videos of academic presentation from Harvard University. She knows the channel from one of her lecturer. From the videos she got a lot of new topics including NML. In contrary, the future teacher who get the lowest score is very rarely reading materials or browsing some new topics on the internet. She only study what have been teach from her lecturers and do not have motivation to find out some new topics out of the teaching materials provided by the lecturers.

Kindrergarten Future Teachers' Understanding on New Media and Its Program that Suitable for Children.

One of the media literacy skill elements is that children have to get familiar with many kinds of media, including digital media (Silawati et al, 2018). Digital tools are possible to be used as learning media for children including in building some aspects of their characters but its program must be appropriate for the children (Silawati\& Setyaningsih, 2017). Furthermore, according to American Academy of Paediatrics / AAP (2016) that media digital program which is suitable for children have to consider children's health, contains educational values as well as give entertainment for children. Consequently, the future teachers have to have extensive knowledge on various kinds of gadgets and its characteristics program that suitable for children.

In summary, the data analysis shows that 27 participants comprehend very well about the various kinds of gadgets. They also understand the appropriate program for children. Moreover only 3 participants that have medium score in this part. The data is presented on the table 2 below.

Table 2. Number of Frequency of Future Teachers' Understanding on Various Kinds of Media Future Teachers' Understanding Number of Frequency

Fully Comprehended Less




\begin{tabular}{lccc}
\hline & Comprehended & Comprehended \\
Various Kinds of Media & 27 & 3 & 0 \\
\hline
\end{tabular}

From the in dept interview, it is found that the highest score participant understand this topic because it has been explained in one of the subjects (Media and ICT for Children). In other hand the lowest score participant cannot answer the question because she attends the class rarely and do not have motivation to learn independently.

Kindrergarten Future Teachers' Understanding on Teaching NML to Children

The third question is about future teachers' understanding on teaching NML to children. In general, teaching activities is involve some proccess such as, learning planning, learning implementation and learning evaluation. Each of the proccess is important in developing effective learning activities including teaching NML to children. The first step is learning planning which is very vital in order to ensure holistically of all developmental aspects in every daily activity through students' active involvement (Curtis \& O'Hagan, 2003). However, it is not easy to arranged this process because a teacher should through some stages such as: 1) determining developmental stages in particular ages, 2) determining developmental indicators that will be developed, 3) analysing learning materials that will be introduced to children, 4) determining learning themes, 5) arranging learning activities and 6) developing learning media (Dirjen PAUD, 2012). Fortunately, this topic has been discussed on one of the subjects (Learning Planning in the Context of Early Childhood Education), that is why the participant score for learning planning is pretty high.

According to the data analysis, it is found that the participants' understanding of learning plan is above other elements of learning even though their total score of each element in this part is still low. The data is presented on the table below.

Table 2. Number of Frequency of Future Teachers' Understanding on Teaching NML to Children

\begin{tabular}{lccc}
\hline Future Teachers' Understanding & \multicolumn{3}{c}{ Number of Frequency } \\
\cline { 2 - 4 } & $\begin{array}{c}\text { Fully } \\
\text { Comprehended }\end{array}$ & Comprehended & $\begin{array}{c}\text { Less } \\
\text { Comprehended }\end{array}$ \\
Learning Planning & 10 & 13 & 17 \\
Learning Implementation & 7 & 11 & 12 \\
Learning Evaluation & 2 & 10 & 18 \\
\hline
\end{tabular}

From the interview of the highest score participant, it is clear stated that she comprehends learning planning very well because they have already learned it in one of the subjects (Learning planning in the context of Early Childhood Education). However, their understanding of learning planning is still in general, not in the context of teaching NML. As consequences, their knowledge of how to teach NML to children is still needed to be improved.

\section{Conclusions}

The society 5.0 need people who have NML skill. This skill should be encourage as early as possible. Therefore kindergarten future teachers need to be prepare to master the strategy of teaching NML to children. From the data analysis it can be concluded that future teachers comprehend very well in some aspects, such as: kinds of media that suitable for children. Nevertheless, they are still less comprehending in understanding other elements of NML as well as its teaching strategies. Consequently, it is recommended to develop this topic into curriculum of Early Childhood Teacher Education Study Program.

\section{Acknowledgments}


This paper is a part of on going research project that funded by Universitas Pendidikan Indonesia. Thank you for the students of Early Childhood Teacher Education Study Program of Universitas Pendidikan Indonesia who have involve in this study as participans, data collectors and data analysts.

\section{References}

AAP (2016) . AAP Announces New Recommendations for Children's Media Use. Retrieved from https://healthychildren.org/English/news/Pages/AAP-Announces-New-Recommendationsfor-Childrens-Media-Use.aspx

Alper, Meryl. (2011). Developmentally Appropriate New Media Literacies: Supporting Cultural Competencies and Social Skills in Early Childhood Education. Journal of Early Childhood Literacy. Vol.13(2) 175-196. DOI: 10.1177/1468798411430101.

Creswell, John W. (2012). Educational Research, Planning, Conducting and Evaluating quantitative and qualitative Research Forth Edition. Boston: Pearson.

Curtis, A. \& O'Hagan, M. (2003) Care and Education In Early Childhood, A Students' Guide To Theory And Practice. London and New York: Routledge Falmer.

Dirjen PAUD. (2012). Bahan ajar diklat berjenjang tingkat dasar, perencanaan kegiatan pembelajaran. Jakarta: Depdikbud.

Fidler, David. (2016). Future Skills, Update and Literature Review, USA: Institute for the Future for ACT Foundation and the Joyce Foundation.

I-Scoop. (2018) From industry 4.0 to Society 5.0: The big societal Transformation Plan of Japan Retrieved from https://www.i-scoop.eu/industry-4-0-society-5-0/

Jenkins, Henry. (2006) Confronting the Challenges of Participatory Culture: Media Education for the 21 ${ }^{\text {st }}$ Century. Chicago, IL : The John D. and Catherine T. McArthur Foundation.

Kara, Mehmet. et al (2018) Validating of an Instrument for Preservice Teachers and an Investigation of their New Media Literacy. Journal of Educational Computing Research. Vol. 56(7) 1005-1029.

Kurnia, Tommy. (2018). 5 Negara dengan Jumlah Pengguna Media Sosial terbanyak, Indonesia Berapa? Retrieved from https://www.liputan6.com/tekno/read/3481323/5-negara-denganjumlah-pengguna-media-sosial-terbanyak-indonesia-berapa

Luke, Carmen. (2007). As Seen on TV or Was that My Phone? New Media Literacy. Policy Futures in Education, Vol. 5(1) 50-58.

Republic of Indonesia. Law No. 14 Year 2005 on Teachers and Lecturers.

Silawati, Endah. et al. (2018). Literasi Media Anak Usia Dini: Strategi Penanggulangan Kekerasan Seksual pada Anak. Semarang: Proceeding of Edusainteks Unimus.

Silawati, Endah \& Setyaningsih, Rachmania. (2017). Character Building of Young Children through Gadget as Learning Media in Kindergarten. Advances in Social Science, Education and Humanities Research, $3^{\text {rd }}$ International Conference on early Childhood Education (ICECE-16), Vol.58, 152-156.

UPI Kampus Cibiru. (2018). Survei Kepuasan Lulusan Program Study PGPAUD UPI Kampus Cibiru, Bandung: UPI Kampus Cibiru.

The Scottish Government. (2015). Literature review on the Impact of Digital technology on Learning and teaching. Edinburgh: ICF Consulting Services Ltd. 